\title{
Regulation of proliferation and differentiation of adipocyte precursor cells in rainbow trout (Oncorhynchus mykiss)
}

\author{
L Bouraoui, J Gutiérrez and I Navarro \\ Departament de Fisiologia, Facultat de Biologia, Universitat de Barcelona, Avda Diagonal 645, 08028 Barcelona, Spain \\ (Correspondence should be addressed to I Navarro; Email: mnavarro@ub.edu)
}

\begin{abstract}
Here, we describe optimal conditions for the culture of rainbow trout (Oncorhynchus mykiss) pre-adipocytes obtained from adipose tissue and their differentiation into mature adipocytes, in order to study the endocrine control of adipogenesis. Pre-adipocytes were isolated by collagenase digestion and cultured on laminin or $1 \%$ gelatin substrate. The expression of proliferating cell nuclear antigen was used as a marker of cell proliferation on various days of culture. Insulin growth factor-I stimulated cell proliferation especially on days 5 and 7 of culture. Tumor necrosis factor $\alpha(\mathrm{TNF} \alpha)$ slightly enhanced cell proliferation only at a low dose. We verified the differentiation of cells grown in specific medium into mature adipocytes by oil red $\mathrm{O}(\mathrm{ORO})$ staining. Quantification of ORO showed an increase in triglycerides throughout culture.
\end{abstract}

Immunofluorescence staining of cells at day 11 revealed the expression of CCAAT/enhancer-binding protein and peroxisome proliferator-activator receptor $\gamma$, suggesting that these transcriptional factors are involved in adipocyte differentiation in trout. We also examined the effect of $\mathrm{TNF} \alpha$ on the differentiation of these adipocytes in primary culture. TNF $\alpha$ inhibited the differentiation of these cells, as indicated by a decrease in glycerol-3-phosphate dehydrogenase activity, an established marker of adipocyte differentiation. In conclusion, the culture system described here for trout pre-adipocytes is a powerful tool to study the endocrine regulation of adipogenesis in this species.

Journal of Endocrinology (2008) 198, 459-469

\section{Introduction}

The high lipid content of diets used in aquaculture can induce an increase in fat depots that may affect animal health and decrease the productivity of this sector, especially in salmonids. In fish, like in mammals, the development of adipose tissue and accumulation of lipids is a continuous process that depends on genetic, hormonal, and dietary factors, which include the hypertrophy of existing adipocytes and the proliferation and differentiation of new ones. Therefore, in order to understand the development of adiposity, it is crucial to identify the factors that regulate the formation of adipocytes from precursor cells in the adipose tissue. In comparison with cell culture lines, primary cell cultures are more likely to represent the in vivo condition because cells are removed directly from the animal and grown in relatively simple culture medium (Hausman \& Poulos 2005). In mammals, primary cell cultures have contributed to unraveling the major processes involved in adipogenesis, such as the proliferation of precursor cells and the differentiation of these cells into adipocytes. This type of culture system has been developed only in two fish species (Vegusdal et al. 2003, Oku et al. 2006). Nevertheless, from the data obtained in mammals, it can be concluded that factors that regulate adipogenesis differ considerably between species.
Furthermore, the use of a primary cell culture from a simple model, such as a vertebrate ectotherm, may allow study of the basic mechanisms of adipocyte biology and thereby contribute to clarifying pathological situations like obesity in humans.

Proliferation and differentiation are usually alternative and mutually exclusive pathways for cells (Freytag 1988, Freytag \& Geddes 1992), and growth arrest is considered a requirement for adipocyte differentiation (Smyth et al. 1993). Among the multiple factors involved in this process in mammals, CCAAT/enhancer-binding protein (C/EBP) and peroxisome proliferator-activator receptor $\gamma(\operatorname{PPAR} \gamma)$ have been identified as transcriptional factors (MacDougald \& Lane 1995) and are necessary for the transition of pre-adipocytes into adipocytes in vitro.

In mammals, insulin growth factor-I (IGF-I) affects adipocyte proliferation and differentiation in vivo and in vitro (Wright \& Hausman 1995, Butterwith 1997, Gregoirie et al. 1998, MacDougald \& Mandrup 2002). This factor exerts its biological effects through a complex signaling pathway that involves the activation of specific cell surface receptors (Blüher et al. 2005). IGF-I is a mitogenic and differentiation factor for various mammalian cell lines, and primary stromalvascular cell cultures, including pre-adipocytes (Smith et al. 1988, Schmidt et al. 1990, Richardson et al. 1998). IGF-I has 
mitogenic and anabolic effects in fish myocytes in culture (Castillo et al. 2004). This growth factor induces proliferation, measured as thymidine incorporation, in primary cell cultures of trout myocytes (Castillo et al. 2004) as well as DNA synthesis in zebrafish embryonic cells (Pozios et al. 2001). However, to our knowledge, the effects of IGF-I in fish adipocyte lineage have not been studied, although IGF-I binding has been characterized in brown trout (Salmo trutta) adipose tissue (Planas et al. 2000).

Tumor necrosis factor $\alpha(\mathrm{TNF} \alpha)$ is a multifunctional cytokine that is synthesized and secreted from macrophages and adipose tissue in mammals (Hotamisligil et al. 1994), and its expression and production increases with augmented adipocyte size (Morin et al. 1997). The catabolic and antiadipogenic effects of TNF $\alpha$ decrease adipose conversion in various cell lines as well as in rat, porcine, and human primary cells (Grégoire et al. 1992, Hotamisligil et al. 1994, Vassaux et al. 1994, Boney et al. 1996, Boone et al. 2000). TNF $\alpha$ acts directly on lipid metabolism by decreasing parameters related with fatty acid uptake (decrease in lipoprotein lipase (LPL), fatty acid transport (FAT), and fatty acid transport protein (FATP) expressions) and lipogenesis (decrease in fatty acid synthase (FAS), acetyl-CoA carboxylase (ACC) expression, and glycerol-3-phosphate dehydrogenase (GPDH) activity), and by increasing lipolysis (Dani et al. 1989, Sethi \& Hotamisligil 1999). TNF $\alpha$ mRNA expression has been reported in primary rainbow trout monocytes (Zou et al. 2002) and in adipose tissue of sea bream (Saera-Vila et al. 2007). In rainbow trout (Oncorhynchus mykiss), TNFa contributes to lipid metabolism by stimulating lipolysis in vivo and in vitro (Albalat et al. 2005). The interaction of TNF $\alpha$ and IGF-I on adipocyte development has also been examined. The specific responses of developing pre-adipocytes to TNFa may be influenced by the presence of IGF-I (Kras et al. 2000).

Very few studies on the culture of pre-adipocytes in vitro have been attempted in fish (Vegusdal et al. 2003, Oku et al. 2006). A protocol for studying the proliferation and differentiation of these cells in Atlantic salmon adipose tissue has been described (Vegusdal et al. 2003). These authors observed that PPAR $\gamma, \mathrm{C} / \mathrm{EBP}$, and leptin were expressed in mature adipocytes grown in culture, as shown for mammals, and the supplementation of $10 \%$ of fetal bovine serum (FBS) to the culture medium did not affect pre-adipocyte differentiation. Furthermore, the effects of insulin, triiodothyronine $\left(\mathrm{T}_{3}\right)$, and fat-soluble vitamins (all-trans retinoic acid, retinyl acetate, and 1,25 dihydroxyvitamin D3) on adipocyte differentiation and LPL gene expression have been analyzed in cultures derived from the stromal-vascular cells of red sea bream (Pagrus major), using serum-free culture conditions (Oku et al. 2006).

Nevertheless, information on the regulation of adipogenesis is still scarce and the role of IGF-I and TNF $\alpha$ has not been analyzed in fish adipocytes. Rainbow trout is one of the most common cultured fresh water fish species. The final product can be affected by excess visceral fat and therefore a greater understanding of adipogenesis in this species is of value to aquaculture industries. The establishment of culture conditions that favor the proliferation and differentiation of trout pre-adipocytes is required to gain a better understanding of molecular and physiological mechanisms of adipose tissue development and accumulation. Here, we define the optimal conditions for the culture of rainbow trout pre-adipocytes and their differentiation into mature adipocytes, in order to study the control of these processes by endocrine and adipokinetic factors. Specifically, we analyzed the effect of serum, IGF-I, and TNF $\alpha$ on pre-adipocyte proliferation and the action of TNF $\alpha$ on adipocyte differentiation. The presence of differentiating transcription factors, such as PPAR $\gamma$ and C/EBP, was also demonstrated.

\section{Materials and Methods}

\section{Cell preparation and culture conditions}

Rainbow trout (O. mykiss) between 200 and $250 \mathrm{~g}$ were obtained from the 'Truchas del Segre' fish farm (Lleida, Spain). Fish were acclimatized to environmental conditions at $18 \pm$ $1{ }^{\circ} \mathrm{C}$ and natural photoperiod in facilities at the University of Barcelona (Faculty of Biology) in closed circuit flow systems. They were fed daily ad libitum with a commercial diet (DIBAQ AQUATEX, Segovia, Spain). Fish were killed by a sharp blow to the head. They were weighed and perivisceral adipose tissue was excised by sterile dissection. This tissue was minced into sections of $\sim 1 \mathrm{~mm}^{2}$, and after one wash with Krebs-HEPES

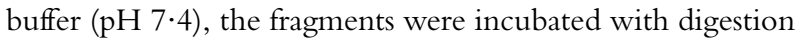
medium Krebs-HEPES buffer containing 1\% BSA (SigmaAldrich) and $130 \mathrm{UI} / \mathrm{ml}$ collagenase (type II, Sigma-Aldrich). The minced tissue was incubated for $1 \mathrm{~h}$ with gentle shaking at a speed of 50 shakes $/ \mathrm{min}$ in a water bath at $18^{\circ} \mathrm{C}$. The cell suspension was passed through a $100 \mu \mathrm{m}$ filter to remove large undigested tissues. The suspension was then centrifuged at $\sim 700 \mathrm{~g}$ for $10 \mathrm{~min}$. Floating mature adipocytes and medium were removed. The cell pellet was treated with erythrocyte lysing buffer $\left(0 \cdot 154 \mathrm{M} \mathrm{NH}_{4} \mathrm{Cl}, 10 \mathrm{mM} \mathrm{KHCO} 3\right.$, and $0 \cdot 1 \mathrm{mM}$ sodium EDTA) for $10 \mathrm{~min}$ at room temperature. Cells were washed with Krebs-HEPES buffer containing 1\% BSA followed by centrifugation at $700 \mathrm{~g}$ for $10 \mathrm{~min}$. The sedimentary cells were resuspended in growth medium: Dulbecco's modified Eagle's medium (DMEM) containing 10\% FBS, $2 \mathrm{mM}$ L-glutamine, $10 \mathrm{mM}$ HEPES, and $9 \mathrm{mM}$ bicarbonate antibiotics. Cells were counted, diluted, and plated into 24-well plates treated with laminin/poly-D-lysine (LP) or $1 \%$ gelatin at a density of $2 \times 10^{4}$ cells $/ \mathrm{cm}^{2}$ in the medium described above. Cells were maintained at $18{ }^{\circ} \mathrm{C}$ in humidity of $3 \% \mathrm{CO}_{2}$ atmosphere. After $24 \mathrm{~h}$, unattached cells were removed by extensive washing with DMEM. The adherent cells were subsequently maintained in the growth medium until reaching confluence after 1 week. They were then induced to differentiate by means of growth medium supplemented with $10 \mu \mathrm{g} / \mathrm{ml}$ insulin, $0.5 \mathrm{mM}$ 3-isobutyl-1methylxanthine (IBMX), $0.25 \mu \mathrm{M}$ dexamethasone, and 
$10 \mu \mathrm{l} / \mathrm{ml}$ lipid mixture, which contained $45 \mu \mathrm{g} / \mathrm{ml}$ cholesterol, $100 \mu \mathrm{g} / \mathrm{ml}$ cod liver oil FA, $250 \mu \mathrm{g} / \mathrm{ml}$ polyoxyethylene sorbitan monooleate, and $20 \mu \mathrm{g} / \mathrm{ml} \mathrm{D}-\boldsymbol{\alpha}$-tocopherol acetate (Sigma-Aldrich; referred to as differentiation medium). Cells in differentiation and growth medium were grown in parallel. Media were replaced every 2 days.

\section{Cell proliferation and IGF-I effects}

Cell proliferation was evaluated by immunostaining with a primary mouse monoclonal antibody directed against the proliferating cell nuclear antigen (PCNA; clone PC10; Zymed Laboratories, Inc., Barcelona, Spain). We compared cell proliferation in plates pre-coated with LP and $1 \%$ gelatin at $10 \%$ FBS (days 3, 5, 7, 9, and 11).

To test the effects of IGF-I on pre-adipocyte proliferation, the plates were coated with $1 \%$ gelatin. Cells were incubated with or without recombinant human IGF-I at $100 \mathrm{nM}$ (Reutlingen, Germany), in a medium containing 2 or $5 \%$ FBS (days 3, 5, 7, and 9).

Cells from both the experiments were immunostained for PCNA on days $3,5,7$, and 9. The procedure was followed simultaneously in cells with and without IGF-I treatment. Cells were washed in PBS and fixed in ethanol for $20 \mathrm{~min}$ at $4{ }^{\circ} \mathrm{C}$. Cells were then treated with $3 \% \mathrm{H}_{2} \mathrm{O}_{2}$ for 10 min to block endogenous peroxidase activity. After three washes, primary antibody raised against PCNA was applied for $1 \mathrm{~h}$, the goat antimouse biotin-labeled secondary antibody was added for $10 \mathrm{~min}$; and the avidin-biotin peroxidase complex (ABC; Dako) was applied for $10 \mathrm{~min}$. 3,3'-diaminobenzidine was used as the chromogen. Cells were counterstained with Mayer's hematoxylin for $2 \mathrm{~min}$ and washed in water. Finally, cells were dehydrated in a graded alcohol series and mounted with histomount. The PCNA-labeling index was expressed as the percentage of the number of PCNA-labeled nuclei divided by the total number of nuclei examined under a microscope.

\section{Combined effect of IGF-I and TNF $\alpha$ on pre-adipocyte proliferation}

Another experiment was performed to study the combined effect of IGF-I and TNF $\alpha$ on cell proliferation. Twenty-four hours after seeding on $1 \%$ gelatin, cells were cultured in DMEM containing $2 \mathrm{mM}$ L-glutamine, $10 \mathrm{mM}$ HEPES, $9 \mathrm{mM}$ bicarbonate antibiotics, and 2\% FBS. Cells were then exposed to recombinant human IGF-I (Mediagnost; $100 \mathrm{nM}$ ) or human recombinant TNF $\alpha$ at 10 and $100 \mathrm{ng} / \mathrm{ml}$ (SigmaAldrich) in separate wells. Besides, IGF-I (100 nM) was added together with $\mathrm{TNF} \alpha$ at different concentrations (10 and $100 \mathrm{ng} / \mathrm{ml})$. Cells cultured in growth medium in the absence of both hormones were used as control.

On day 5 , cells were immunostained with a primary mouse monoclonal antibody directed against the PCNA (clone PC10; Zymed Laboratories, Inc.) to evaluate proliferative cells as described above.

\section{Pre-adipocyte differentiation}

Oil red O (ORO) staining of cell culture To visualize cell morphology and lipid accumulation, on day 11, cells cultured in the two media (growth and differentiation medium) were stained with ORO following Ramírez-Zacarías et al. (1992). Media from three culture wells per condition were aspirated. After two washes, cells were fixed with cold $10 \%$ neutral buffered formalin for $30 \mathrm{~min}$ and then rinsed with water. They were then stained with ORO $(0 \cdot 35 \mathrm{~g}, 60 \%$ isopropanol) for $2 \mathrm{~h}$. Cells were exhaustively rinsed with water and the nuclei were counterstained using Mayer's hematoxylin for $2 \mathrm{~min}$. Finally, stained cells were rinsed with running tap water.

\section{Quantification of lipid accumulation}

Estimation of cell accumulation of lipid droplets as triglycerides was based on the protocol described by Laughton (1986) with slight modifications. The procedure is based on ORO staining of neutral lipids and Coomassie brilliant blue staining of cellular protein. Cells from three wells from three separate experiments were fixed with perchloric acid and after washing were incubated with ORO dissolved in propylene glycol $(2 \mathrm{mg} / \mathrm{ml})$ for $2 \mathrm{~h}$ at room temperature. Cells were first washed thrice with $85 \%$ propylene glycol and twice with water. The ORO within the lipid droplets was extracted using isopropanol for $10 \mathrm{~min}$ at room temperature. Sample $(100 \mu \mathrm{l})$ was measured using a microplate reader at $490 \mathrm{~nm}$ and blanked to cell-free wells. Next, the wells were emptied and washed for protein determination. Cells were incubated with Coomassie brilliant blue for $1 \mathrm{~h}$ at room temperature. After washing the cells twice with water, they were incubated with propylene glycol for $3 \mathrm{~h}$ at $60^{\circ} \mathrm{C}$ to extract Coomassie stain. Sample $(100 \mu \mathrm{l})$ was measured using a microplate reader at $630 \mathrm{~nm}$ and blanked to cell-free wells. The specific lipid content was calculated as the ratio of absorbance value obtained for ORO and Coomassie blue staining.

\section{Assay of GPDH activity}

Cell differentiation was assessed by quantifying GPDH activity. The measurement was performed following Sottile \& Seuwen (2001) with slight modifications. Cells were grown and induced to differentiate in 24-well plates. At day 16, cells were washed with PBS and an ice-cold homogenization solution was added $(20 \mathrm{mM}$ Tris- $\mathrm{HCl}, 1 \mathrm{mM}$ EDTA, and $1 \mathrm{mM} \beta$-mercaptoethanol, $\mathrm{pH} \mathrm{7 \cdot 3)}$ and cells were then stored at $-20{ }^{\circ} \mathrm{C}$ for $1 \mathrm{~h}$. Frozen plates were allowed to thaw at room temperature. After mechanical processing of samples with a gauge needle, the assay mixture was added to each well $(0.1 \mathrm{M}$ triethanolamine, $2.5 \mathrm{mM}$ EDTA, $0.1 \mathrm{mM}$ $\beta$-mercaptoethanol, and $334 \mu \mathrm{M} \mathrm{NADH}, \mathrm{pH} 7 \cdot 7$ ) and plates were incubated for $10 \mathrm{~min}$ at $30^{\circ} \mathrm{C}$. The reaction was started by adding $4 \mathrm{mM}$ dihydroxyacetone phosphate. GPDH 
activity was measured spectrophotometrically at $340 \mathrm{~nm}$. The protein content of cell cultures was determined by the Bradford method. Results were expressed as $\mathrm{mU} / \mathrm{mg}$ protein (1 $\mathrm{U}=1 \mu \mathrm{mol} \mathrm{NADH} / \mathrm{min})$.

\section{Immunofluorescence staining}

Cells cultured on glass cover slips until day 11 were fixed with $3 \%$ paraformaldehyde in PBS for $15 \mathrm{~min}$ at room temperature. After washing with PBS-glycine (PBS-Gly), cells were permeabilized with $0 \cdot 05 \%$ Triton X-100 in PBS-Gly for $10 \mathrm{~min}$ at room temperature. After being washed with PBSGly, cells were blocked with 1\% BSA in PBS-Gly for $20 \mathrm{~min}$ at room temperature. They were then incubated with primary antibody PPAR $\gamma(1: 50)$ or C/EBP (1:100; Santa Cruz Biotechnology, Santa Cruz, CA, USA) in PBS-Gly containing 1\% BSA for $1 \mathrm{~h}$ at room temperature, washed for 10 min in PBS-Gly, and incubated with an Alexa Fluor488conjugated goat anti-rabbit antibody (1:500), as a secondary antibody, in combination with Hoechst (1:1000). After washing with PBS, cells were mounted with Mowiol, and immunofluorescence was captured with a confocal microscope (Confocal Olympus Fluoview 500).

\section{Immunoprecipitation}

Cells at day 11 were treated with lysis buffer $(10 \mathrm{mM}$ Tris-HCl, $140 \mathrm{mM} \mathrm{NaCl}, 5 \mathrm{mM}$ EDTA, $1 \mathrm{mM}$ phenylmethanesulphonylfluoride or phenylmethylsulphonyl fluoride, $50 \mathrm{mM}$ sodium orthovanadate, $10 \mu \mathrm{g} / \mathrm{ml}$ aprotinin, $10 \mu \mathrm{g} / \mathrm{ml}$ leupeptin, and $1 \%$ Nonidet P-40, pH 7·6). The cell suspension was centrifuged for $15 \mathrm{~min}$ at $16000 \mathrm{~g}$ and the supernatant was stored at $-80^{\circ} \mathrm{C}$ until analysis. Lysates were pre-cleaned by the addition of $50 \mu \mathrm{l}$ Protein A-Sepharose (GE Healthcare Bio-Sciences AB) in immunoprecipitate buffer $(10 \mathrm{mM}$ Tris- $\mathrm{HCl}, 140 \mathrm{mM} \mathrm{NaCl}$, and $5 \mathrm{mM}$ EDTA). After $1 \mathrm{~h}$ at $4{ }^{\circ} \mathrm{C}$, samples were centrifuged for $30 \mathrm{~s}$ at $16000 \mathrm{~g}$, the supernatant was transferred to a fresh tube, and incubated with $2 \mu \mathrm{g}$ anti-PPAR $\gamma$ antibody for $1 \mathrm{~h}$. Subsequently, $50 \mu \mathrm{l}$ Protein A-Sepharose was added and incubated overnight at $4{ }^{\circ} \mathrm{C}$. Samples were washed three times in immunoprecipitate buffer and analyzed by SDS-PAGE.

\section{Western blot}

The presence of PPAR $\gamma$ in cell cultures was evaluated by western blot analysis. On days 5 and 11, cells grown in the differentiation medium were lysed. After one wash in PBS, cells were harvested in lysis buffer and frozen at $-80{ }^{\circ} \mathrm{C}$ until analysis. Homogenates of adipose tissue from trout were used as a control to confirm the specificity of PPAR $\gamma$ immunodetection. Protein content was determined using the Bradford method (Braddford 1976). Proteins $(50 \mu \mathrm{g})$ were separated by $10 \%$ SDS-polyacrylamide gel and transferred on PVDF membrane for $2 \mathrm{~h}$ at $100 \mathrm{~V}$. After $3 \times 5 \mathrm{~min}$ washes with buffer $(10 \mathrm{mM}$ Tris- $\mathrm{HCl}, 100 \mathrm{mM} \mathrm{NaCl}$, and $0 \cdot 1 \%$ Tween 20, pH 7·5), the membrane was blocked with washing buffer containing $5 \%$ dry milk for $2 \mathrm{~h}$ at room temperature. The blot was probed with anti-PPAR $\gamma$ antibody (Santa Cruz Biotechnology) diluted 1:500 overnight at $4{ }^{\circ} \mathrm{C}$. The following day, the membrane was incubated for $1 \mathrm{~h}$ at room temperature with secondary antibody conjugated to horseradish peroxidase. Antibody band was visualized by chemiluminescence (ECL).

\section{Effect of TNF $\alpha$ on cell differentiation}

To evaluate the effect of TNF $\alpha$ on adipocyte differentiation, cells were grown to confluence (day 7) and exposed to recombinant human TNF $\alpha$ (Sigma-Aldrich). At confluence, growth medium was replaced by differentiation medium containing DMEM, glutamine, and antibiotics as listed previously but without lipid mixture, and supplemented with insulin $(10 \mu \mathrm{g} / \mathrm{ml})$, IBMX $(0.5 \mathrm{mM})$, dexamethasone $(0 \cdot 25 \mu \mathrm{M})$, and several concentrations of TNF $\alpha(1,10$, and $100 \mu \mathrm{g} / \mathrm{ml})$. Control 1 cells were cultured in growth medium, control 2 contained differentiation medium without lipid mixture while control 3 cells were cultured with differentiation medium with lipid mixture. Media were replaced every 2 days.

\section{Statistical analysis}

Data are given as mean \pm S.E.M. Results were analyzed by oneway ANOVA followed by Tukey's test. The effect of substrate on proliferation was analyzed by paired $t$-test. Differences were considered significant when $P<0 \cdot 05$.

\section{Results}

\section{Cell morphology and proliferation}

Here, we provide the first description of conditions to maintain primary trout pre-adipocyte cultures. Phase contrast microscopy at day 1 showed that most cells were attached and small (Fig. 1A). Throughout their development, the cells cultured in growth medium maintained an elongated and fibroblast-like phenotype with an extended cytoplasm, devoid of large lipid droplets (Fig. 1B and C), and very few started spontaneous differentiation.

We compared the proliferation of cells grown on LP and $1 \%$ gelatin substrate in the presence of $10 \%$ FBS. Cells grown on gelatin proliferated to a slightly greater extent than those on LP at days 3 and 5 in the presence of growth medium (Fig. 2). Cells still continued to proliferate after confluence in the presence of differentiation medium, although at a slower rate, reaching the maximum and similar level of proliferation at day 9 in both LP and gelatin. At day 11, a decrease in PCNA staining was detected in both substrates, indicating diminished proliferative capacity after differentiation. Cell density increased in a similar way in the two substrates and no differences were observed in cell attachment, spread, or 

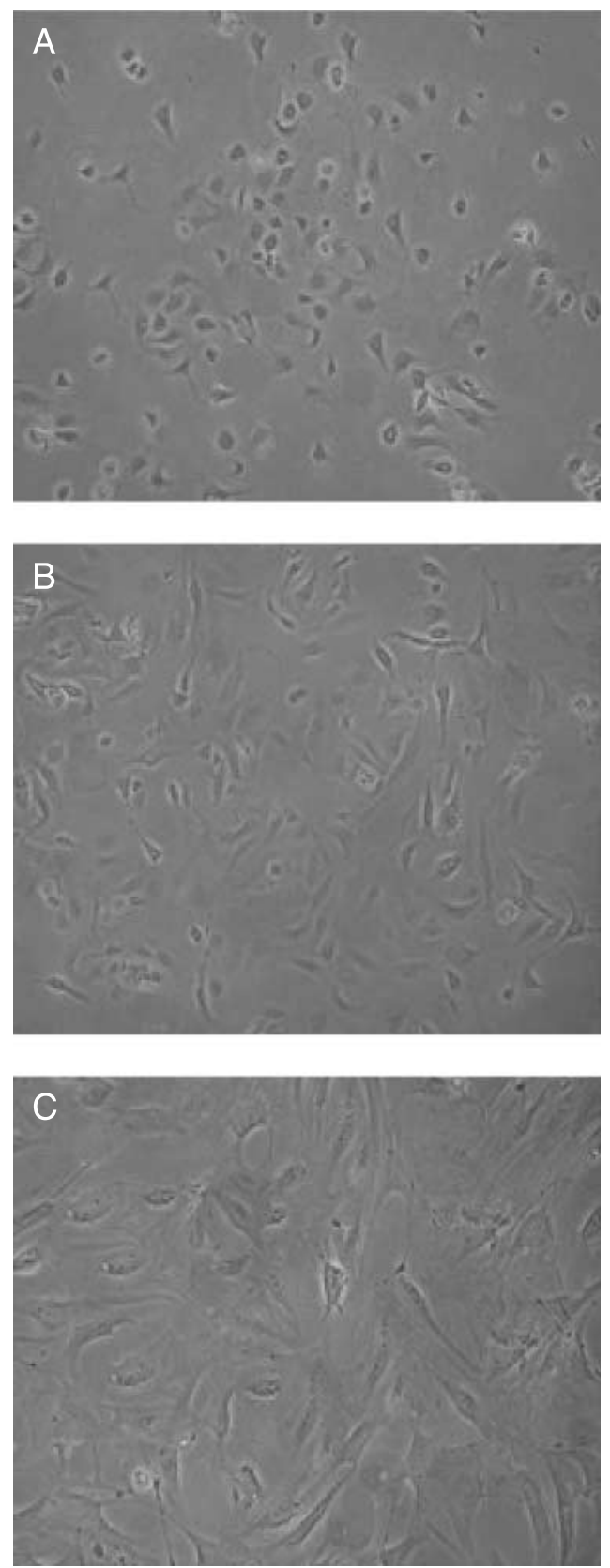

Figure 1 Photomicrographs of trout pre-adipocyte cells isolated from perivisceral adipose tissue at different days of growth. Cells were grown on $1 \%$ gelatin substrate until confluence at day 7 in the presence of $10 \%$ FBS. Cells on $(A)$ day $1,(B)$ day 5 , and $(C)$ day $7(\times 20)$.

growth. We used $1 \%$ gelatin as a substrate for the subsequent experiments.

\section{Effect of IGF-I on proliferative activity}

To evaluate the effect of IGF-I on pre-adipocyte proliferation, on day 1 , cells were incubated in growth medium

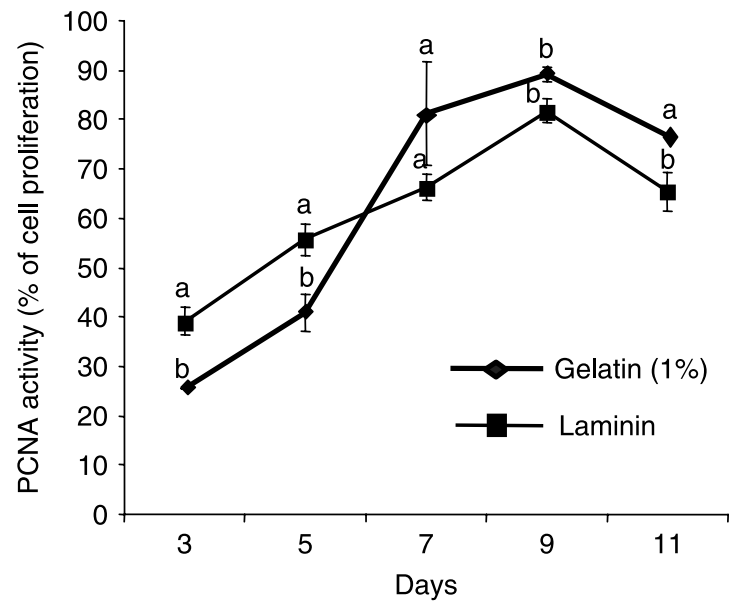

Figure 2 Percentage of PCNA-labeled primary culture of preadipocytes from rainbow trout. Data expressed as mean \pm S.E.M. for days $3,5,7,9$, and $11, n=3$ from three independent cultures. Where error bars are not visible, they are contained within the symbol. Different letters indicate differences between groups $(P \leq 0 \cdot 05)$.

supplemented with $100 \mathrm{nM}$ IGF-I, at a range of FBS concentrations $(2-5 \%)$ in order to minimize the effects of serum factors. IGF-I induced proliferation to a similar degree at 5 and 2\% FBS (Fig. 3). A comparison of the distinct conditions at day 5 showed that proliferation was significantly lower in the absence of IGF-I at $2 \%$ FBS. At day 7 (confluence), both the decrease in serum concentration and the absence of IGF-I induced significant decreases in

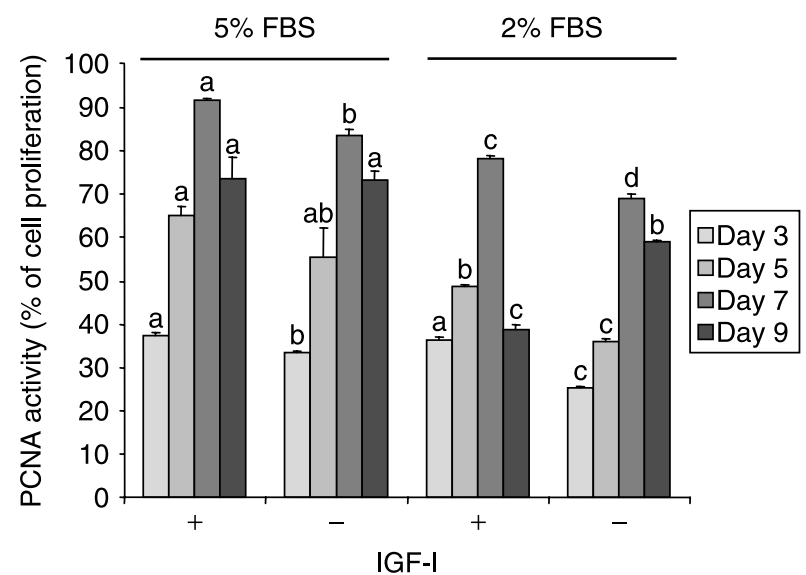

Figure 3 Effect of exposure to recombinant human IGF-I on the proliferative capacity of trout pre-adipocytes. Cells were isolated and seeded at $2 \times 10^{4}$ cells $/ \mathrm{cm}^{2}$ on plates pre-coated with $1 \%$ gelatin. On day 1 , cells were incubated with IGF-I (+) at $100 \mathrm{nM}$ or without (-), in growth medium containing 2 or $5 \%$ fetal bovine serum (FBS), for $3,5,7$, and 9 days. $n=3$ from three independent cultures. Data are expressed as mean \pm s.E.M., and the results from the same day were compared between different groups (2 and 5\% FBS, with and without IGF-I). Different letters indicate differences between groups $(P \leq 0 \cdot 05)$. 
proliferation. At day 9, no clear effect of IGF-I was observed on the proliferative activity of differentiated cells.

\section{Combined effect of IGF-I and TNF $\alpha$ on pre-adipocyte proliferation}

The effect of simultaneous incubation with IGF-I and TNF $\alpha$ on cell proliferation was also examined. Cells were cultured in $2 \%$ FBS and exposed to several treatments: control, IGF-I $(100 \mathrm{nM})$, TNF $\alpha(10$ and $100 \mathrm{ng} / \mathrm{ml})$, IGF-I $(100 \mathrm{nM})+$ $\mathrm{TNF} \boldsymbol{\alpha}(10 \mathrm{ng} / \mathrm{ml})$, and IGF-I $(100 \mathrm{nM})+\mathrm{TNF} \boldsymbol{\alpha}(100 \mathrm{ng} / \mathrm{ml})$. IGF-I alone stimulated cell proliferation at day 5 (Fig. 4). The addition of TNF $\alpha$ at low dose $(10 \mathrm{ng} / \mathrm{ml})$ showed a tendency to stimulate cell proliferation. At $100 \mathrm{ng} / \mathrm{ml}$, TNF $\alpha$ had no effect on pre-adipocyte proliferation. However, when applied together, TNF $\alpha$ and IGF-I promoted cell proliferation. This promotion was only significant at a low concentration of TNF $\alpha$, but no synergistic effect was observed.

\section{Cell differentiation}

Identification and quantification of lipid accumulation At confluence, pre-adipocytes were induced to differentiate into adipocytes in the presence of diverse hormone/factors $(10 \mu \mathrm{g} / \mathrm{ml}$ insulin, $0 \cdot 25 \mu \mathrm{M}$ dexamethasone, and $0.5 \mathrm{mM}$ IBMX) and lipid mixture (see Materials and Methods). Under these conditions, typical changes in cell morphology during differentiation were observed (Fig. 5). Cells lost their fibroblast-like appearance and became larger and spherical. Cytoplasms gradually accumulated small lipid droplets. The detection of these droplets was visualized by ORO staining (Fig. 5B2). By contrast, cells incubated in

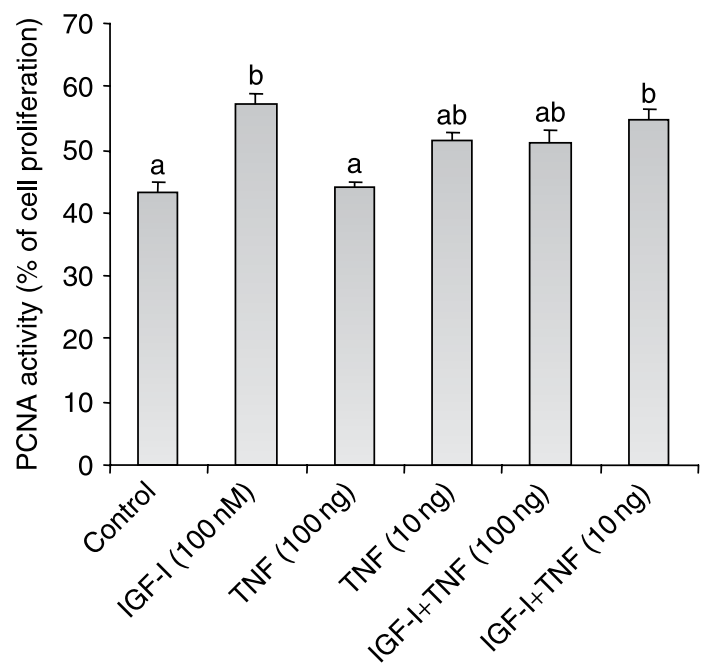

Figure 4 Effect of TNF $\alpha$ and IGF-I on pre-adipocyte proliferation. Cells at day 1 were cultured in growth medium and $2 \%$ of FBS, and exposed to several conditions: control (without IGF-I), $100 \mathrm{nM}$ IGF-I, 10 and $100 \mathrm{ng} / \mathrm{ml} \mathrm{TNF} \alpha$, IGF-I $+10 \mathrm{ng} / \mathrm{ml} \mathrm{TNF} \alpha$, IGF-I+ $100 \mathrm{ng} / \mathrm{ml}$ TNF $\alpha$. Cells were immunostained with PCNA antibody on day 5 .
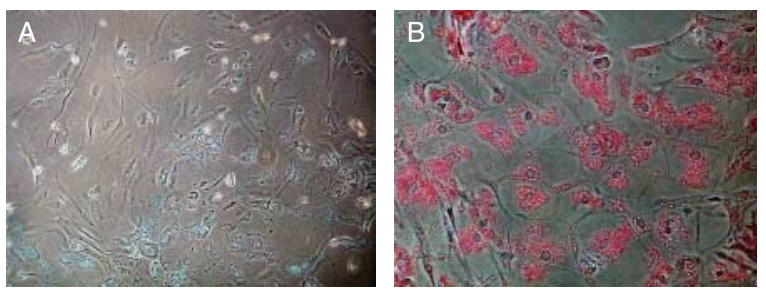

Figure 5 Photomicrographs of trout adipose stromal-vascular cells and adipocytes in primary culture stained with oil red $O$ on day 11. (A) Undifferentiated cells cultured in growth medium. (B)

Differentiated cells in the presence of $10 \mu \mathrm{g} / \mathrm{ml}$ insulin, $0 \cdot 25 \mu \mathrm{M}$ dexamethasone, and $0.5 \mathrm{mM}$ IBMX supplemented with lipid mixture $(\times 40)$.

growth medium alone during the same period of culture preserved their fibroblast-like morphology (Fig. 5B1). Quantification of the accumulation of triglyceride containing lipid droplets throughout the culture (labeled with ORO in cells and extracted with isopropanol) is shown in Fig. 6. ORO staining on days 3-7 demonstrated that cells accumulated significantly less lipid, especially at day 3 . The replacement of proliferation to differentiation medium at day 7 increased lipid accumulation, and the highest level of triglycerides was observed at day 11 of culture.

\section{Presence of PPAR $\gamma$ and $C / E B P$ in trout adipocytes}

To identify the factors involved in adipocyte differentiation, we performed immunofluorescence staining of PPAR $\gamma$ and $\mathrm{C} / \mathrm{EBP}$. These two transcription factors were localized in the nuclei, as revealed by Hoechst staining (Fig. 7). Hormonal cocktail and lipid mixture contained in the differentiation

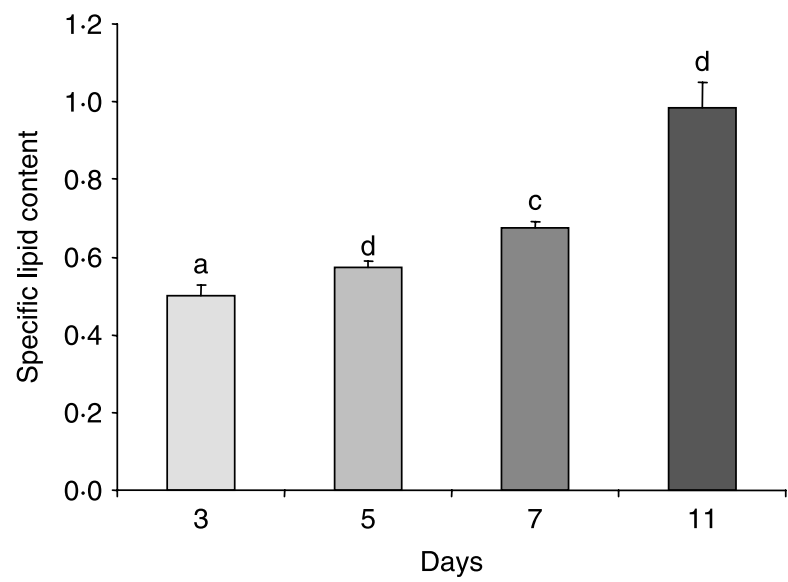

Figure 6 Specific lipid content expressed spectrophotometrically as the ratio of absorbance value obtained for ORO and Coomassie blue staining. Triglyceride accumulation in trout adipocytes cultured in growth medium (days 3,5 , and 7 ). On day 7 , medium was replaced by the differentiation medium containing $10 \mu \mathrm{g} / \mathrm{ml}$ insulin, $0 \cdot 25 \mu \mathrm{M}$ dexamethasone, and $0.5 \mathrm{mM} \mathrm{IBMX}$ supplemented with lipid mixture, as described in Materials and Methods. Data from five experiments (four wells per experiment) are shown as mean \pm S.E.M. Different letters indicate differences between groups $(P \leq 0 \cdot 05)$. 


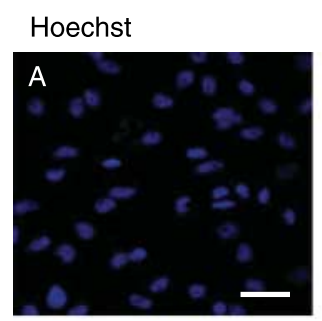

PPAR $\gamma$
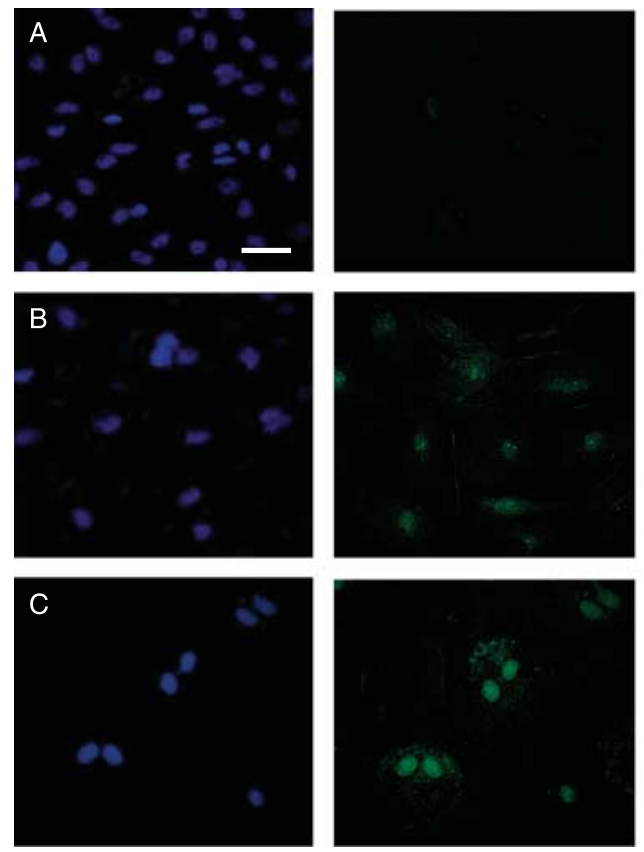
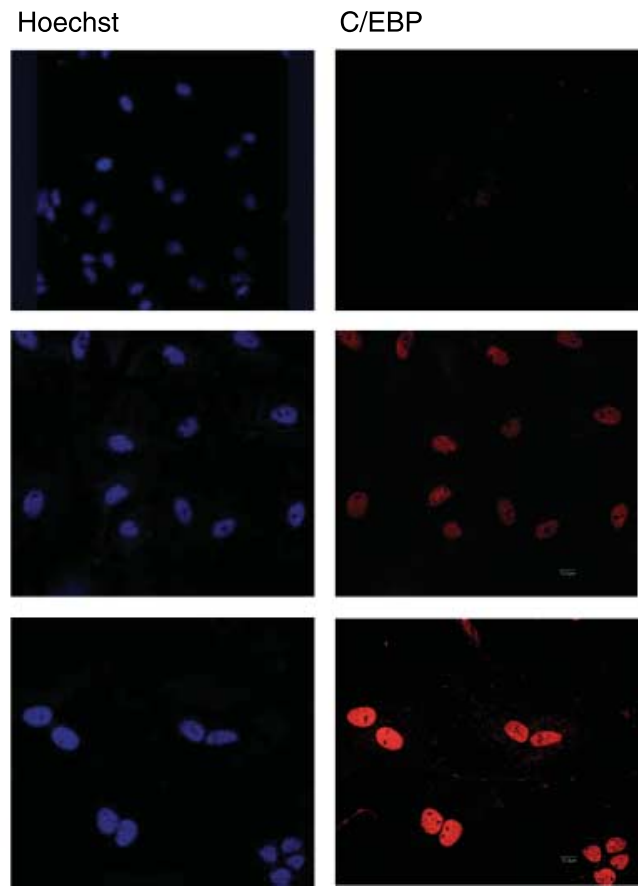

Figure 7 Adipocyte immunofluorescence using PPAR $\gamma$ and C/EBPantibodies. All groups were incubated with secondary Ab PE-conjugated goat anti-rabbit $\mathrm{F}\left(\mathrm{ab}^{\prime}\right) 2$. Cell nuclei were counterstained with Hoechst. Hoechst staining is shown in the first and third panels in blue, PPAR $\gamma$ staining in the second panel in green, and C/EBP $\alpha$ in the fourth panel in red. (A) Cells incubated with PBS, (B) proliferating cells with primary antibodies (PPAR $\gamma$, $\mathrm{C} / \mathrm{EBP} \alpha$ ), and (C) differentiating cells with PPAR $\gamma$, and C/EBP $\alpha$ primary antibodies. Bar, $10 \mu \mathrm{m}$.

medium added from days 7 to 11 induced the expression of PPAR $\gamma$ and C/EBP (Fig. 7C). By contrast, cells grown in growth medium showed very low protein expression (Fig. 7B). No signal was detected in differentiated cells incubated with PBS instead of PPAR $\gamma$ or C/EBP antibodies (Fig. 7A).

The specificity of the band for PPAR $\gamma$ detected by western blot was checked by immunoprecipitation (Fig. 8). Western blot revealed the presence of one specific protein band corresponding to PPAR $\gamma(54 \mathrm{kDa})$ with higher intensity in differentiated cells (day 11) than in proliferated cells (day 5). These results suggest that PPAR $\gamma$ and C/EBP participate as transcription factors in the early stages of adipogenesis.

\section{Effect of TNF $\alpha$ on the differentiation of trout adipocytes}

We evaluated the degree of differentiation in trout adipocyte culture at day 16 using GPDH activity as an indicator of this

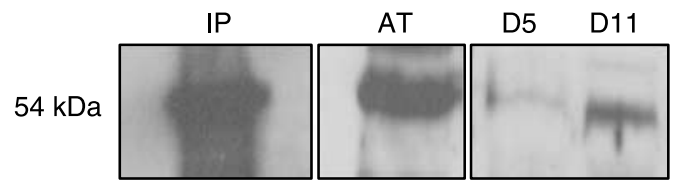

Figure 8 Protein band of PPAR $\gamma$ expressed in trout adipocyte at days 5 and 11 . Cells at day 11 were immunoprecipitated with $2 \mu \mathrm{g}$ $\mathrm{Ab}$ anti-PPAR $\gamma$ (IP) and a homogenate of adipose tissue from trout (AT) was used as a control. cellular process (Fig. 9). The activity of this enzyme increased from $54 \cdot 35 \pm 4 \cdot 28 \mathrm{mU} / \mathrm{mg}$ protein before differentiation of cells cultured in the absence of any adipogenic stimuli and in the presence of $10 \%$ FBS (control 1) up to $\sim 86.27 \pm 15.26 \mathrm{mU} / \mathrm{mg}$ protein in cells maintained in differentiation medium containing $10 \mu \mathrm{g} / \mathrm{ml}$ insulin, $0 \cdot 25 \mu \mathrm{M}$ dexamethasone, and $0.5 \mathrm{mM}$ IBMX but without lipid mixture (control 2). The highest level of GPDH was observed when we supplemented the differentiation medium with lipid mixture $(145 \cdot 17 \pm 10 \cdot 58 \mathrm{mU} / \mathrm{mg}$ protein; control 3). The addition of increasing doses of TNF $\alpha$ (1, 10, and $100 \mathrm{ng} / \mathrm{ml}$ ) to the differentiation medium (without lipid mixture) inhibited differentiation. GPDH activity was reduced significantly at $100 \mathrm{ng} / \mathrm{ml} \mathrm{TNF} \alpha$ (Fig. 9). The suppression reached almost $50 \%$ of control values (control 2). The reduction of GPDH was accompanied by similar decrease in lipid accumulation and no effect of TNF $\alpha$ was observed on cell number (data not shown).

\section{Discussion}

Here, we provide the first description of a cell culture system to grow and differentiate trout pre-adipocytes into adipocytes. In mammals, many factors are involved in the proliferation and differentiation of these cells in primary culture (Hausman 

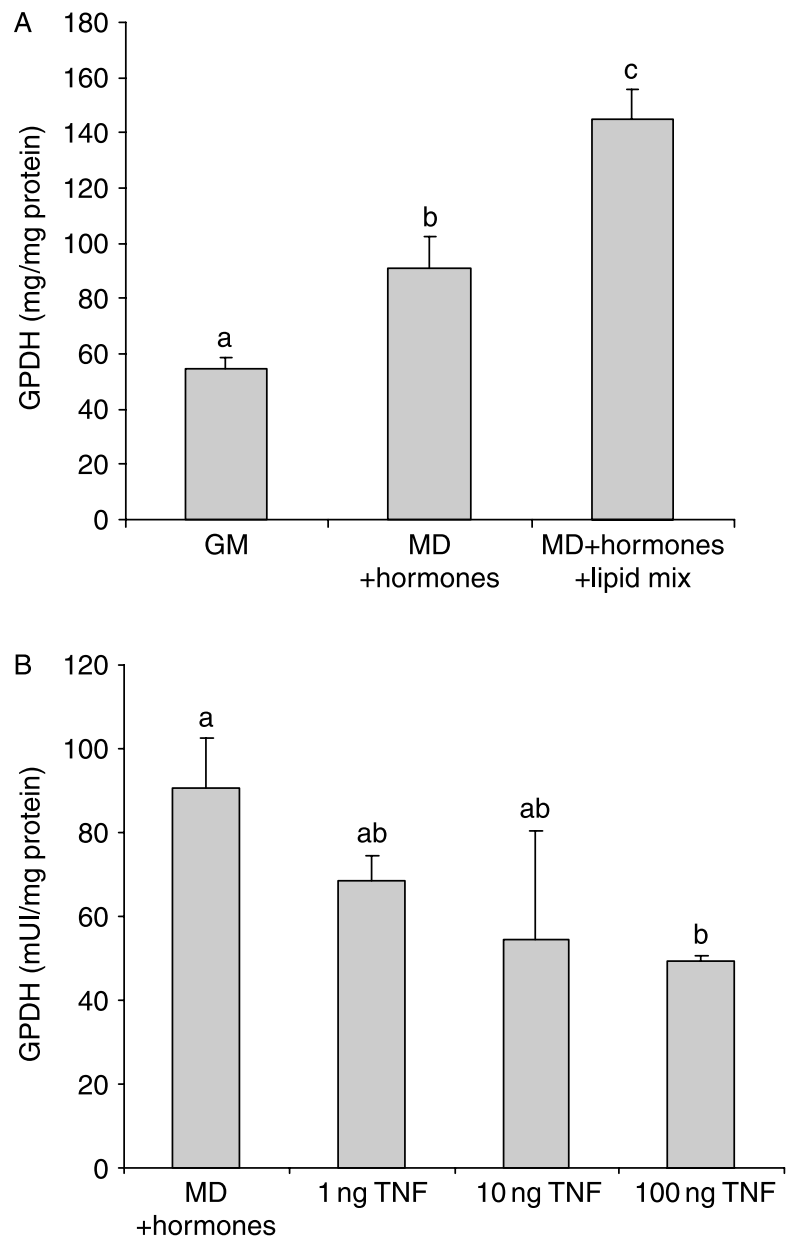

Figure 9 GPDH activity of adipocytes used as a marker of adipogenesis. (A) At confluence (day 7), cells were incubated in growth media (control 1), differentiation media without lipid mixture (control 2), and differentiation media supplemented with lipid mixture (control 3). (B) Cells were exposed to differentiation media in the presence of hormones without lipid mixture (as described above), supplemented with 1, 10, and $100 \mathrm{ng} / \mathrm{ml}$ TNF $\alpha$. Data from two experiments (three to four wells per experiment) are shown as mean \pm S.E.M. Different letters indicate differences between groups $(P \leq 0 \cdot 05)$.

et al. 2001). However, little information is available on the processes regulating proliferation in fish. The use of either LP or $1 \%$ gelatin as substrate resulted in pre-adipocyte proliferation. Differences between the two substrates were observed on days 3 and 5, with greater proliferation in cells cultured in gelatin. Cells were attached, spread, and developed well on both substrates and although proliferation was fastest between days 5 and 7 of culture in $1 \%$ gelatin, the two substrates reached a similar final level of proliferation on day 9. Our study is the first to use gelatin for pre-adipocyte attachment and proliferation in fish. Most studies in mammals have used laminin as substrate in primary cell culture, as in porcine stromal-vascular cultures, in which laminin increases the number, size, and proportion of adipocytes (Hausman et al. 1996). Other studies have described that differentiating pre-adipocytes show greater adherence to laminin than nonpre-adipocytes. The poly-D-lysine was also used as a substrate as it contributes to the attachment of cells and the formation of a uniform monolayer, but this substrate impaired porcine pre-adipocyte development (Yu \& Hausman 1998). To date, few studies have applied gelatin as a substrate in pre-adipocyte cultures. Plates coated with gelatin increase human adipostromal cell number and proliferation (Inoue et al. 2005). Furthermore, gelatin provides an extracellular matrix that maintains proliferation and increases viability, both of which may be desirable for long-term cultures (Aidan et al. 2007).

Here, we tested the effect of IGF-I and TNF $\alpha$ on proliferation in primary cultures of trout pre-adipocytes. Mammalian IGF-I and TNF peptides are effective in fish systems in vitro, and numerous examples have been reported (Duan 1998, Albalat et al. 2005, Saera-Vila et al. 2007, Codina et al. 2008). Fish and mammalian IGF-I also give similar results in binding studies (Leibush et al. 1996, Navarro et al. 1999, Castillo et al. 2002). Comparison of the sequences of fish genes and peptides with those of mammals indicates that these factors have been conserved throughout vertebrate evolution, (Duan 1998, Laing et al. 2001, García-Castillo et al. 2002), which is consistent with the conservation of their biological potency.

IGF-I is a potent paracrine/autocrine adipogenic and mitogenic factors in mammals. This hormone is considered to be the major regulator of cell proliferation and differentiation of pre-adipocytes into adipocytes (Blüher et al. 2005). The addition of IGF-I to pre-adipocyte cell lines and primary cultures induces both mitogenic and differentiation responses in rat and pig (Ramsay et al. 1989, Schmidt et al. 1990, Ramsay 2000). Although our study did not examine the potential action of IGF-I on differentiation, we found that recombinant human IGF-I stimulated the proliferation of rainbow trout pre-adipocytes. This observation is consistent with the findings of studies on other species, in which IGF-I effectively triggers this process (Nougues et al. 1993, Wright \& Hausman 1995, Butterwith 1997). In mammals, preadipocytes express IGF-I receptors (Blüher et al. 2005). Furthermore, the adipose tissue of brown trout expresses IGF-I receptors (Planas et al. 2000). On the basis of findings from studies on mammalian stromal-vascular cells, preadipocytes, and adipocytes (Shimizu et al. 1986, Smith et al. 1988, Ramsay 2000), we propose that trout pre-adipocytes also present these receptors. The signaling pathway by which IGF-I could stimulate cell proliferation is through activation of MAPK as shown in 3T3-L3 pre-adipocytes (Blüher et al. 2005). In our study, the proliferative action of IGF-I on cells was improved by the presence of factors or nutrients in the serum, like the mitogenic competence factor, which enhances IGF-I-induced proliferation (McWade et al. 1995).

IGF-I and TNF $\alpha$ are both known as paracrine factors, with opposing effects on adipose cell differentiation. IGF-I induces 
both mitogenic and differentiation responses in pre-adipocyte cultures (Wabitsch et al. 1995), whereas TNFa inhibits the expression of adipogenic enzymes (Boone et al. 2000). Nevertheless, TNF $\alpha$ can also act as a stimulatory factor of cell proliferation at low doses in rat stromal-vascular cell cultures (Kras et al. 2000) or fibroblast cell lines including BALB/3T3 and 3T-L1 (Palombella \& Vilcek 1989, Cornelius et al. 1990). In the present study, trout cell culture was shown to be slightly responsive to the proliferative action of TNF $\alpha$.

Our study focuses on the possible effects of co-incubation of IGF-I with TNF $\alpha$ on the growth of pre-adipocytes. The combination of both hormones promoted proliferation but without a synergistic effect. However, in stromal-vascular cell culture of rat (Kras et al. 2000), low levels of TNF $\alpha$ stimulated proliferation and acted synergistically with IGF-I to further enhance proliferation. The net result of this interaction would be an increase in the uncommitted cell pool from which these cells might then be mostly recruited to become adipocytes or other cell types supporting adipose tissue growth (Kras et al. 2000).

The culture of trout pre-adipocytes in differentiation medium containing insulin, dexamethasone, IBMX, and lipid mixture, in the presence of $10 \%$ FBS, resulted in increased lipid accumulation, as evidenced by ORO staining, and this medium was essential to initiate the differentiation of these cells into mature adipocytes. Nevertheless, the lipid mixture is important in trout adipocyte differentiation. Salmon pre-adipocytes differentiate only in the presence of lipid mixture (Vegusdal et al. 2003). However, the differentiation of red sea bream stromal-vascular cells is induced when linoleic acid, in the presence of insulin and $\mathrm{T}_{3}$, is applied (Oku et al. 2006). Fatty acids play a pivotal role in cell differentiation in fish. By contrast, the presence of lipids is not a requisite for the differentiation of pre-adipocyte cell lines and primary pre-adipocytes derived from distinct fat depots in mammals, including rodents, rabbits, and pigs (Gregoirie et al. 1998, Van Harmelen et al. 2004, Niemela et al. 2007), in which hormones such as insulin, dexamethasone, and IBMX exert a greater effect on adipocyte differentiation.

GPDH is a lipogenic enzyme involved in cell differentiation. In our study, the medium containing insulin, dexamethasone, and IBMX stimulated GPDH activity, which is used as a differentiation parameter in many species (Ramsay \& Rosebrough 2003, Van Harmelen et al. 2004). This combination of hormones induced approximately a twofold increase in GPDH activity when we supplemented cultures with lipid mixture. Again, this observation indicates the importance of the presence of fatty acids in trout preadipocyte differentiation. GPDH activity also increases during the differentiation of salmon pre-adipocytes (Vegusdal et al. 2003) and in primary culture of bovine adipocytes in the presence of oleate (Sato et al. 1996).

Our study is the first to demonstrate the effect of TNF $\alpha$ on fish adipogenesis. This cytokine is a negative regulator of adipogenesis in several adipocyte models (Smyth et al. 1993). In our study, the treatment of cells with $\mathrm{TNF} \alpha$ in culture decreased GPDH activity. Similar results have been described in rat adipocytes and 3T3-L1 (Smas \& Sul 1995, Xing et al. 1997, Kras et al. 2000). TNF $\alpha$ can act on lipid metabolism by decreasing the expression of lipoprotein lipase and by increasing lipolysis in 3T3-L1 adipocytes (Morin et al. 1995, Holden \& Pakula 1996). The effects observed in trout preadipocyte culture are consistent with the inhibition of lipoprotein lipase activity by $\mathrm{TNF} \alpha$ in isolated trout adipose tissue (Albalat et al. 2006) and the increase in lipolysis in isolated trout adipocytes (Albalat et al. 2005).

Adipocyte differentiation is induced by a series of programed changes in gene expression in mammals (Hwang et al. 1997). PPAR $\gamma$ and $\mathrm{C} / \mathrm{EBP} \alpha$ are key adipogenic transcription factors (Tchkonia et al. 2002). In the current study, the expression of PPAR $\gamma$ and $\mathrm{C} / \mathrm{EBP} \alpha$ in trout adipocyte was detected by immunofluorescence, and PPAR $\gamma$ protein levels detected by western blot increased with differentiation of cells. This is in agreement with results found by Vegusdal et al. (2003) who reported the presence of PPAR $\gamma$ and $\mathrm{C} / \mathrm{EBP} \alpha$ in salmon adipocytes by western blot and immunocytochemistry, suggesting an adipogenic function of these factors also in fish. Other studies have shown the expression of PPAR $\gamma$ and $\mathrm{C} / \mathrm{EBP} \alpha$ in porcine adipose precursor cells (Hausman 2000, Kim \& Moustaid-Moussa 2000). Studies in transgenic animal models have shown that adipogenesis is blocked when these factors are absent (El Jack et al. 1999). Furthermore, PPAR $\gamma$ and $\mathrm{C} / \mathrm{EBP} \alpha$ activate adipocyte-specific genes and are involved in the growth arrest required for adipocyte differentiation in humans (Niemela et al. 2007). The adipocyte model offers a valuable tool to study the role of these factors during the regulation of adipose tissue growth.

In conclusion, we have established culture conditions for supporting proliferation and differentiation of pre-adipocyte cells isolated from trout adipose tissue and to study the endocrine regulation of these processes. This in vitro model will be very helpful to understand the pattern of gene expression involved in the control of adipogenesis and to obtain markers for the proliferation and differentiation capacity of the adipose tissue.

\section{Declaration of Interest}

The authors declare that there is no conflict of interest that could be perceived as prejudicing the impartiality of the research reported.

\section{Funding}

This study was supported by the 'Ministerio de Educación y Ciencia' (MEC; AGL2004-06319-CO2-02/ACU) and the 'Centre de Referencia de Recerca Desenvolupament en Aqüicultura de la Generalitat de Catalunya' (CRA 2006-304008). 


\section{Acknowledgements}

We thank J Baró from the 'Truites del Segre' fish farm (Lleida, Spain) for providing the rainbow trout and J Guinea from the 'Estabulari de la Facultat de Biologia' for maintaining the fish.

\section{References}

Aidan M, Fiona L, Peter K \& Hugh B 2007 Growth substrate induced functional changes elucidated by FTIR and Raman spectroscopy in in vitro cultured human keratinocytes. Analytical and Bioanalytical Chemistry 387 1717-1728.

Albalat A, Liarte C, MacKenzie S, Tort L, Planas JV \& Navarro I 2005 Control of adipose tissue lipid metabolism by tumor necrosis factor- $\alpha$ in rainbow trout (Oncorhynchus mykiss). Journal of Endocrinology 184 527-534.

Albalat A, Sánchez-Gurmaches J, Gutiérrez J \& Navarro I 2006 Regulation of lipoprotein lipase activity in rainbow trout (Oncorhynchus mykiss) tissues. General and Comparative Endocrinology 146 226-235.

Blüher S, Kratzsch J \& Kiess W 2005 Insulin-like growth factor I, growth hormone and insulin in white adipose tissue. Best Practice and Research. Clinical Endocrinology and Metabolism 19 577-587.

Boney CM, Fiedorek FT, Paul SR \& Gruppuso PA 1996 Regulation of preadipocyte factor-1 gene expression during 3T3-L1 cell differentiation. Endocrinology $1372923-2928$.

Boone C, Mourot J, Grégoire F \& Remacle C 2000 The adipose conversion process: regulation by extracellular and intracellular factors. Reproduction, Nutrition, Development 40 325-358.

Braddford MM 1976 A rapid and sensitive method for quantitation of microgram quantities of protein utilizing the principle of protein-dye binding. Analytical Biochemistry 72 248-252.

Butterwith SC 1997 Regulators of adipocyte precursor cells. Poultry Science 76 118-123.

Castillo J, Le Bail PY, Paboeuf G, Navarro I, Weil C, Fauconneau B \& Gutierrez J 2002 IGF-I binding in primary culture of muscle cells of rainbow trout: changes during in vitro development. American Journal of Physiology. Regulatory, Integrative and Comparative Physiology 283 R647-R652.

Castillo J, Ammendrup-Johnsen I, Codina M, Navarro I \& Gutiérrez J 2004 Metabolic and mitogenic effects of IGF-I and insulin on muscle cells of rainbow trout. American Journal of Physiology. Regulatory, Integrative and Comparative Physiology 286 R 935-R941.

Codina M, García de la serrana D, Sánchez-Gurmaches J, Montserrat N, Chistiakova O, Navarro I \& Gutiérrez J 2008 Metabolic and mitogenic effects of IGF-II in rainbow trout (Oncorhynchus mykiss) myocytes in culture and the role of IGF-II in the PI3K/Akt and MAPK 4 signalling pathways. General and Comparative Endocrinology 157 116-126.

Cornelius P, Marlowe M, Lee MD \& Pekala PH 1990 The growth factor-like effects of tumor necrosis factor-alpha. Stimulation of glucose transport activity and induction of glucose transporter and immediate early gene expression in 3T3-L1 preadipocytes. Journal of Biological Chemistry 265 20506-20516.

Dani C, Doglio A, Amri E-Z, Bardon S, Fort P, Bertrand B, Grimaldi P \& Ailhaud G 1989 Cloning and regulation of a mRNA specifically expressed in the preadipose state. Journal of Biological Chemistry 264 10119-10125.

Duan C 1998 Nutritional and developmental regulation of insulin-like growth factors in fish. Journal of Nutrition 128 306S-314S.

El Jack AK, Hamm JK, Pilch PF \& Farmer SR 1999 Reconstitution of insulin-sensitive glucose transport in fibroblasts require expression of both PPAR $\gamma$ and C/EBP $\alpha$. Journal of Biological Chemistry 274 7946-7951.

Freytag SO 1988 Enforced expression of the c-myc oncogene inhibits cell differentiation by precluding entry into a distinct predifferentiation state in G0/G1. Molecular and Cellular Biology 4 1614-1624.

Freytag SO \& Geddes TJ 1992 Reciprocal regulation of adipogenesis by Myc and C/EBP $\alpha$. Science 17 379-382.
García-Castillo J, Pelegrín P, Mulero V \& Meseguer J 2002 Molecular cloning and expression analysis of tumor necrosis factor alpha from a marine fish reveal its constitutive expression and ubiquitous nature. Immunogenetics $\mathbf{5 4}$ 200-207.

Grégoire F, De Broux N, Hauser N, Heremans H, van Damme J \& Remacle C 1992 Interferongamma and interleukin- $1 \beta$ inhibit adipoconversion in cultured rodent preadipocytes. Journal of Cellular Physiology 151 300-309.

Gregoirie FM, Smas CM \& Sul HS 1998 Understanding of adipocyte differentiation. Physiological Reviews 78 783-806.

Van Harmelen V, Röhrig K \& Hauner H 2004 Comparison of proliferation and differentiation capacity of human adipocyte precursor cells from the omental and subcutaneous adipose tissue depot of obese subjects. Metabolism 53 632-637.

Hausman GJ 2000 The influence of dexamethasone and insulin on expression of CCAAT/enhancer binding protein isoforms during preadipocyte differentiation in porcine stromal-vascular cell cultures: evidence for very early expression of C/EBP $\alpha$. Journal of Animal Science 78 1227-1235.

Hausman GJ \& Poulos SP 2005 A method to establish co-cultures of myotubes and preadipocytes from collagenase digested neonatal pig semitendinosus muscles. Journal of Animal Science 83 1010-1016.

Hausman GJ, Wright JT \& Richardson RL 1996 The influence of extracellular matrix substrata on preadipocyte development in serum-free cultures of stromal-vascular cells. Journal of Animal Science 74 2117-2128.

Hausman DB, DiGirolamo MT, Bartness J, Hausman GJ \& Martin RJ 2001 The biology of white adipocyte proliferation. Obesity Reviews 2 239-254.

Holden RJ \& Pakula IS 1996 The role of tumor necrosis factor-a in the pathogenesis of anorexia and bulemia nervosa, cancer cachexia and obesity. Medical Hypotheses 47 423-438.

Hotamisligil GS, Murray D, Choy LN \& Spiegelman BM 1994 TNF- $\alpha$ inhibits signaling from insulin receptor. PNAS 91 4854-4858.

Hwang CS, Loftus MT, Mandrup S \& Daniel M 1997 Adipocyte differentiation and leptin expression. Annual Review of Cell and Developmental Biology 13 231-259.

Inoue S, Hori Y, Hirano Y, Inamoto T \& Tabata Y 2005 Effect of culture substrate and fibroblast growth factor addition on the proliferation and differentiation of human adipo-stromal cells. Journal of Biomaterials Science. Polymer Edition 16 57-77.

Kim S \& Moustaid-Moussa N 2000 Secretory, endocrine an autocrine/ paracrine function of the adipocyte. Journal of Nutrition 130 3110S-3115S.

Kras KM, Hausman DB \& Martin RJ 2000 Tumor necrosis factor-a stimulates cell proliferation in adipose tissue-derived stromal-vascular cell culture: promotion of adipose tissue expansion by paracrine growth factors. Obesity Research 8 186-193.

Laing KJ, Wang T, Zou J, Holland J, Hong S, Bols N, Hirono I, Aoki T \& Secombes CJ 2001 Cloning and expression analysis of rainbow trout Oncorhynchus mykiss tumour necrosis factor-alpha. European Journal of Biochemistry 268 1315-1322.

Laughton C 1986 Measurement of the specific lipid content of attached cells in microtiter cultures. Analytical Biochemistry 156 307-314.

Leibush B, Parrizas M, Navarro I, Lappova Y, Maestro MA, Encinas M, Plisetskaya EM \& Gutierrez J 1996 Insulin and insulin-like growth factor I receptors in fish brain. Regulatory Peptides 61 155-161.

MacDougald OA \& Lane MD 1995 Transcriptional regulation of gene expression during adipocyte differentiation. Annual Review of Biochemistry $64345-373$.

MacDougald OA \& Mandrup S 2002 Adipogenesis: forces that tip the scales. Trends in Endocrinology and Metabolism 13 5-11.

McWade FJ, Ewton DZ \& Florini JR 1995 Mitogenic competence factor, a serum component that is necessary for IGF-I to stimulate myoblast proliferation and suppresses their ability to stimulate differentiation. Proceedings of the 77th Annual Meeting of the American Endocrine Society, Washington, DC. Abstract P3-206.

Morin CLS, Schlaepfer IR \& Eckel RH 1995 Tumor necrosis factor- $\alpha$ eliminates binding of NF-Y and octamer-binding protein to the lipoprotein lipase promoter in 3T3-L1 adipocytes. Journal of Clinical Investigation 95 1684-1689. 
Navarro I, Leibush B, Moon TW, Plisetskaya EM, Baños N, Mendez E, Planas JV \& Gutierrez J 1999 Insulin, insulin-like growth factor-I (IGF-I) and glucagon: the evolution of their receptors. Comparative Biochemistry and Physiology. Part B, Biochemistry and Molecular Biology 122 137-153.

Niemela SM, Miettinen S, Konttinen Y, Waris T, Kellomaki M, Nureddin A, Ashammakhi NA \& Ylikomi T 2007 Fat tissue: views on reconstruction and exploitation. Journal of Craniofacial Surgery 8 325-358.

Nougues J, Reyne Y \& Barenton B 1993 Differentiation of adipocyte precursors in a serum-free medium is influenced by glucocorticoids and endogenously produced insulin-like growth factor-1. Journal of Obesity 17 159-167.

Oku H, Tokuda M, Okumura T \& Umino T 2006 Effects of insulin, triiodothyronine and fat soluble vitamins on adipocyte differentiation and LPL gene expression in the stromal-vascular cells of red sea bream, Pagrus major. Comparative Biochemistry and Physiology. Part B, Biochemistry and Molecular Biology 144 326-333.

Palombella VJ \& Vilcek J 1989 Mitogenic and cytotoxic actions of tumor necrosis factor in BALB/c 3T3 cells. Role of phospholipase activation. Journal of Biological Chemistry 264 18128-18136.

Planas JV, Méndez E, Baños N, Capilla E, Navarro I \& Gutiérrez J 2000 Insulin and IGF-I receptors in trout adipose tissue are physiologically regulated by circulating hormone levels. Journal of Experimental Biology 203 $1153-1159$.

Pozios KC, Ding J, Degger B, Upton Z \& Duan C 2001 IGFs stimulate zebrafish cell proliferation by activating MAP kinase and PI3-kinasesignaling pathways. American Journal of Physiology. Regulatory, Integrative and Comparative Physiology 280 R1230-R1239.

Ramìrez-Zacarìa JL, Castro-Munozledo F \& Kuri-Harchuch W 1992 Quantitation of adipose conversion and triglycerides by staining intracytoplasmic lipids with oil red O. Histochemistry 97 493-497.

Ramsay TG 2000 Porcine leptin alters inhibition of lipolysis in porcine adipocytes in vitro. Journal of Animal Science 79 653-657.

Ramsay TG \& Rosebrough RW 2003 Hormonal regulation of postnatal chicken preadipocyte differentiation in vitro. Comparative Biochemistry and Physiology. Part B, Biochemistry and Molecular Biology 136 245-253.

Ramsay TG, White ME \& Wolverton CK 1989 Insulin like growth factor 1 induction of differentiation of porcine pre-adipocytes. Journal of Animal Science 67 2452-2459.

Saera-Vila A, Calduch-Giner JA, Navarro I \& Pérez-Sánchez J 2007 Tumour necrosis factor (TNF) alpha as a regulator of fat tissue mass in the Mediterranean gilthead sea bream (Sparus aurata L.). Comparative Biochemistry and Physiology. Part B, Biochemistry and Molecular Biology 146 338-345.

Sato K, Nakanichi N \& Mitsumoto M 1996 Culture conditions supporting adipose conversión of stromal-vascular cells form bovine intramuscular adipose tissue. Journal of Veterinary Medical Science 58 1073-1078.

Schmidt W, Poll-Jördan G \& Löfler G 1990 Adipose conversion of 3T3-L1 cells in a serum-free culture system depends on epidermal growth factor, insulin-like growth factor I, corticosterone, and cyclic AMP. Journal of Biological Chemistry 265 15489-15495.

Sethi JK \& Hotamisligil GS 1999 The role of TNF $\alpha$ in adipocyte metabolism. Seminars in Cell and Developmental Biology 10 19-29.
Shimizu M, Toni F \& Roth RA 1986 Characterization of the insulin and insulin-like growth factor receptors and responsitivity of a fibroblast/adipocyte cell line before and after differentiation. Biochemical and Biophysical Research Communications 137 552-558.

Smas CM \& Sul HS 1995 Control of adipocyte differentiation. Journal of Biochemistry 309 697-710.

Smith PJ, Wise LS \& Berkowitz R 1988 Insulin-like growth factor-1 is an essential regulator of the differentiation of 3T3-L1 adipocytes. Journal of Biological Chemistry 263 9402-9408.

Smyth MJ, Sparks RL \& Wharton W 1993 Proadipocyte cell lines: models of cellular proliferation and differentiation. Journal of Cell Science 106 1-9.

Sottile V \& Seuwen K 2001 A high-capacity screen for adipogenic differentiation. Analytical Biochemistry 293 124-128.

Tchkonia T, Giorgadze N, Pirtskhalava T, Tchoukalova T, Karagiannides I, Forse RA, DePonte M, Stevenson M, Guo W, Han J et al. 2002 Fat depot origin affects adipogenesis in primary cultured and cloned human preadipocytes. American Journal of Physiology. Regulatory, Integrative and Comparative Physiology 282 R1286-R1396.

Vassaux G, Négrel R, Ailhaud G \& Gaillard D 1994 Proliferation and differentiation of rat adipose precursor cells in chemically defined medium: differential action of anti-adipogenic agents. Journal of Cellular Physiology $161249-256$.

Vegusdal A, Sundvold H, Gjoen T \& Ruyter B 2003 An in vitro method for studying the proliferation and differentiation of Atlantic salmon preadipocytes. Lipids 38 289-296.

Wabitsch M, Hauner H, Heinze E \& Teller WM 1995 The role of growth hormone/insulin-like growth factors in adipocyte differentiation. Metabolism 44 45-49.

Wright JT \& Hausman GJ 1995 Insulin like growth factor-1 (igf-1)-induced stimulation of porcine preadipocyte replication. In Vitro Cellular and Developmental Biology 31 404-408.

Xing H, Northrop JP, Grove JR, Kilpatrick KE, Su JL \& Ringold GM 1997 TNF alpha-mediated inhibition and reversal of adipocyte differentiation is accompanied by suppressed expression of PPAR gamma without effects on Pref-1 expression. Endocrinology 138 2776-2783.

Yu ZK \& Hausman GJ 1998 Preadipocyte screening by laminin in porcine stromal vascular cell cultures. Obesity Research 6 299-306.

Zou J, Wang T, Hirono I, Auki T, Inagawa H, Honda T, Soma GI, Ototake M, Nakanishi T, Ellis AE et al. 2002 Differential expression of two tumor necrosis factor genes in rainbow trout, Oncorhynchus mykiss. Developmental and Comparative Immunology 26 161-172.

Received in final form 29 May 2008
Accepted 25 June 2008

Made available online as an Accepted Preprint 25 June 2008 